\title{
The 'Seychelloisation' of the Seychelles labour market: Policy and constraints of island labour market reform
}

\author{
Paul Thompson \\ School of Management, IT and Governance, University of Kwa-Zulu Natal, South Africa \\ sacar.d.c@gmail.com (corresponding author) \\ Henry Wissink \\ School of Management, IT and Governance, University of Kwa-Zulu Natal, South Africa \\ wissinkh@ukzn.ac.za
}

\section{Zintle Siwisa}

Faculty of Law, University of Fort Hare, South Africa

ZSiwisa@ufh.ac.za

\begin{abstract}
This article explores how the Seychelles post-independence labour market has experienced gradual demographic shifts, due in part to the islands' sustained economic expansion, which has resulted in an increasing dependence on foreign or expatriate labour. The article uses the split labour market theory, in combination with a descriptive research approach based on a single case study qualitative methodology to make sense of the present configuration and some of the structural problems that beset the Seychelles labour market. The main objective of the study is to build on previous analyses of labour market reform initiatives, which are aimed at both alleviating human resources shortages and at the same time control the growing use of expatriate labour. This research also fills a gap in literature from the perspective of the 'Seychelloisation' of the domestic labour market. Research findings demonstrate that the labour localisation (Seychelloisation) quota policies have been constrained by structural barriers such as policy contradictions, perception and tacit social exclusion, an emerging 'mudir syndrome' and rent extraction. The paper also demonstrates that national employment policies alone are not enough to achieve policy targets.
\end{abstract}

Keywords: islands, localization, mudir syndrome, rentierism, Seychelles, Seychellois, Seychelloisation https://doi.org/10.24043/isj.106 • Received December 2018, accepted August 2019

(C) 2019-Institute of Island Studies, University of Prince Edward Island, Canada.

\section{Introduction}

The Republic of Seychelles is an archipelago 'microstate' of 115 islands, otherwise categorised as a small island developing state (SIDS) located off the coast of East Africa in the Indian Ocean. Unlike most continental African countries, the Seychelles is not endowed with an abundance 
of natural or human resources, but instead is blessed with over $1.4 \mathrm{~m} \mathrm{~km}^{2}$ of ocean that form the country's exclusive economic zone (EEZ). Since its independence from Britain in 1976, this SIDS has achieved considerable socioeconomic transformation. Comparatively, by international definition and standards, this microstate has become prosperous within a relatively short space of time. The islands' developmental progress has been so remarkable that Charlier (2016) notes that between 1976 and the mid-2000s, the Seychelles had transformed itself from an agrarian settler colony with a subsistence economy into a high middle-income country with many social indicators comparable to Organisation for Economic Co-operation and Development (OECD) countries.

In light of the Seychelles' socioeconomic success, there has been a multitude of literature by scholars such as Campling, Confiance, and Purvis (2011) and Campling and Rosalie (2006) whose articulations have managed to distil some important features regarding the politics of and pathway to socioeconomic development in the Seychelles. This current article, however, diverges from those and other discourses on the island, such as environmental sustainability and/or the islands' overreliance on tourism and fisheries. Instead, it focuses exclusively on the rationale, policies and challenges in an attempt to localise the domestic labour market; and, by extension, reduce the reliance on foreign labour. The overall significance of this study is that it delves into an understudied area and fills a gap in literature by adding a new perspective on labour market reform debate, through the application of the concept of 'Seychelloisation' (localisation) to the most recent government's 2014 initiative on the regulation of the recruitment of non-Seychellois workers.

The term 'Seychelloisation' has been coined and employed in this paper to designate the policy of manpower regulation and localization, which is of strategic import for the Government of Seychelles. This initiative stems, essentially, from a political desire to moderate the nonantagonistic competition for job opportunities between a growing body of expatriate and potential Seychellois workers. In discussing the pursuit of localisation of the Seychelles labour market, the study is positioned within the split labour market theoretical framework.

Structurally, the article's thematic issues commence with an overview of the islands' growing overdependence on foreign labour. The second section covers the theoretical framework of the study, which situates the study within a split labour market framework. The third section highlights the raisons d'être for the attempted 'Seychelloisation' of the labour market. The fourth is a synopsis of the categorisation of the localisation or 'Seychelloisation' policies. The fifth explores a few constraints and conundrums faced by the Government of Seychelles in the implementation of its most recent labour localisation regulatory framework. The concluding section summarises the salient issues explored and discussed in the body of the study, which is accompanied by recommendations.

\section{Overview of Seychelles' growing dependency on foreign labour}

Seychelles has for a long time been an importer of foreign labour due to its small population and low human resource base (MLHRD, 2014, p.1). However, from a historical perspective, the Seychelles, unlike SIDS in the Caribbean, has had no indigenous population; rather, it comprises people who have immigrated during the last 250 years. As such, the modern nation-state of the Seychelles emerged from being a French/British settler colony slave society into a multiethnic society (Houbert, 2002; IOM, 2014, p.1). The first phase of its dependence on foreign labour 
started when European settlers settled the islands, and with no indigenous population to exploit, the use of foreign (slave) labour was interconnected and intertwined with the settlers' process of primitive capital accumulation. Houbert (2002) further explains how the societies in the Indian Ocean such as the Seychelles and the Mascareignes (Madagascar, Reunion and Mauritius) were created by the same slavery variant on settler colonisation.

The Seychelles' post-colonial era labour market still relies on a growing contingent of non-Seychellois workers, which remains an important source of labour-especially cheap labour-but not limited to this segment of the labour force. When looking at the island from a comparative perspective:

Typical of small states, the Seychelles' labour market is characterized by skills shortage in specific areas of the economy; driven by the growing demand for labour in low skilled and semi-skilled areas which are mostly filled by temporary workers primarily from South and South East Asia. (World Bank, 2011; Personal Interview 4, February 2018)

From observation it would appear that in the labour market situation in the Seychelles, shortages of low- and semi-skilled individuals are not totally about the numerical shortages of workers, but rather concern a partial withdrawal of such skills from the market by individuals, based on sociological and economic factors, some of which are discussed towards the end of paper. These factors have underpinned the Seychelles' continued reliance on foreign labour. The gradual increase in labour market participation by Seychellois women from 2002 onwards has not, unfortunately, fully addressed the issue of reliance on imported labour in the agriculture, tourism, tuna and construction sectors. Labour shortage is not unique to the Seychelles, but similar to, for example, the Arabian Gulf States; the critical danger is that Seychellois government functionaries are unable to persuade some of its low- and/or semi-skilled manpower to take up formal employment in many private-sector enterprises. Therein lies the problem, and if the islands are to maintain their status as a high middle-income country, the government will have to continue facilitating the increasing presence of expatriate labour in the workforce.

One Seychellois manager of a medium-sized construction company adds an important dimension to the discourse, noting that:

Most of our employees are Indians, and the advantages of employing them are that they are more loyal, committed, reliable but not necessarily better skilled than the Seychellois workers. Their attendance rate is $99.9 \%$ and they also work longer hours, approximately 54 hours a week. (Personal interview 3, February 2018)

This is not limited to only Seychellois-owned businesses as it is common to see exclusively expatriate labour in wholesale and retail enterprises owned by entrepreneurs from the Indian subcontinent and Bangladesh. It can be easily argued that the matrix of negation stereotypes highlighted above by the Seychellois manager can also be applied here. Thus, this analysis helps to explain why both state and private-sector actors in the economy continue to develop a growing appetite for Asian workers in particular. Charlier (2016, p.32) attributes the Seychelles' growing dependence on foreign "labour to the lack of international awareness." Even if that is the case, a local resident argued to the contrary, noting that "the very high cost of living in 
coupled with the pro-poor wages offered by many private-sector companies in the Seychelles are significant factors that inhibit many Seychellois from seeking formal employment in some sectors" (Personal interview 5, 15 February 2018). This inhibition tends to crystalise local attitudes and the culture of socioeconomic dependence on government's social services and patronage. Collectively, these have propelled and entrenched especially cheap foreign labour into the orbit of the Seychelles domestic labour market.

Data in Table 1, below, chronicles the historicity and patterns of growth of expatriate workers in the Seychelles private labour market since 2001.

Table 1: Expatriate employment by major occupational groups. Source: Department of Employment, reconstructed by the World Bank.

\begin{tabular}{|l|l|l|l|l|l|l|r|l|l|}
\hline $\begin{array}{l}\text { Occupational } \\
\text { Groups }\end{array}$ & $\mathbf{2 0 0 1}$ & $\mathbf{2 0 0 2}$ & $\mathbf{2 0 0 3}$ & $\mathbf{2 0 0 4}$ & $\mathbf{2 0 0 5}$ & $\mathbf{2 0 0 6}$ & $\mathbf{2 0 0 7}$ & $\mathbf{2 0 0 8}$ & $\mathbf{2 0 1 3}$ \\
\hline Production & 1301 & 970 & 567 & 897 & 1954 & 2254 & 5125 & 6380 & N/A \\
\hline Services & 338 & 613 & 311 & 460 & 416 & 414 & 1157 & 1195 & N/A \\
\hline Prof/technical & 861 & 818 & 796 & 1056 & 1122 & 977 & 1022 & 1164 & N/A \\
\hline Managerial & 281 & 278 & 211 & 303 & 324 & 388 & 433 & 444 & N/A \\
\hline Clerical & 32 & 48 & 29 & 38 & 49 & 92 & 59 & 43 & N/A \\
\hline Elementary & 5 & 7 & 1 & 6 & 25 & 32 & 28 & 24 & N/A \\
\hline Total & $\mathbf{2 8 1 8}$ & $\mathbf{2 7 3 4}$ & $\mathbf{1 9 1 6}$ & $\mathbf{2 7 6 0}$ & $\mathbf{3 8 9 0}$ & $\mathbf{4 1 5 7}$ & $\mathbf{7 8 2 4}$ & $\mathbf{9 2 5 0}$ & $\mathbf{1 3 , 4 1 3}$ \\
\hline
\end{tabular}

A cursory perusal of the data in Table 1 highlights that for Seychellois there is still a limited pool of technical and professional labour in some of the key economic sectors (particularly health, education, hotel and tourism and construction). This is due in part to a gradual but sustained outflow of skilled labour going overseas (including nurses and teachers) (Government of Seychelles and European Union, n.d., p.15). The 2013 figure of approximately 13,413 expatriate workers represents $24.35 \%$ of the islands' labour force consisting of 55,083 people (Vannier \& Uranie, 2014). The total expatriate labour force grew at an average annual rate of $39.7 \%$ between 2001 and 2013. The upward trajectory is reflected in the government's 2016 figures, which showed that the expatriate segment of the labour force had increased with those receiving Gainful Occupation Permits or work permits rose to some 16,792 individuals (World Bank, 2018). Expatriate workers continue to account for approximately $25 \%$ of the labour force. On the contrary, there is no official information available on the corresponding growth of the resident labour force. The scope or magnitude of the increase on the surface may seem insignificant; however, within the context of the Seychelles as a small island state, this is quite substantive. Amid growing use of imported labour on the island, an ironic observation has been made by Campling et al. (2011, p.93) who noted, "one of the key paradoxes of the Seychelles labour market is that $[\ldots]$ there was a growing number of Seychellois who are unemployed and on the Unemployment Relief Scheme."

However, the IMF (2013, p.60) distils the trend by noting, "foreign labour growth in the Seychelles is more strongly correlated with the private sector preference to accommodate changes in demand by varying the number of expatriate workers." Thus, the localisation programme would stand to benefit locals. In summary, the Seychelles' demand for migrant 
labour stems from short-term needs of the business cycle as well as the long-term needs of economic growth and restructuring.

\section{Theoretical framework: Split labour market}

The orthodoxy of split labour market (SLM) has been employed in this article to contextualise the substantive and vital process of localisation or 'Seychelloisation' of the domestic labour market in the Seychelles. As a starting point, the SLM theory, as developed by Bonacich (1972, 1979, 1981), describes class relations as they evolve among three actors: two groups of labourhigher-paid and cheaper labour, usually of different ethnic or racial groups-and business (Bernstein 1998). Split labour market theory was originally advanced as a general approach explaining ethnic antagonism as the result of class-based interests (Corzine, Huff-Corzine \& Creech, 2007). However, at a practical level, in order to be viewed as split, "a labour market must contain at least two groups of workers whose price of labour differs for the same work or would differ if they did the same work" (Bonacich, 1972, p.549).

Price differences amongst many workers is a deeply rooted historical feature of the Seychelles' bifurcated labour market. The duality of the islands' labour market is the outcome of economic forces that encourage the division of workers into two primary sub-groups, namely 'high-priced' and cheap labour. The embedded characteristic of price inequality within the global labour market compelled Bukdugen and Halli (2009) to conclude that split labour market is particularly about racial economic discrimination. For example, comparatively speaking, Euro-American Caucasians historically have sought to secure and are offered a high price for their labour, while cheap labour within the global labour market is the domain of the so-called developing or peripheral countries of the South. As a point of departure, labour market discrimination in the Seychelles is rather contradictory, in the context that the islands' multiracial population is considered in many sectors to have a high reservation price for local labour, which is dissimilar from unskilled, semiskilled expatriate workers from East Africa, India, Bangladesh and the Philippines.

A reading and analysis of the developmental ambitions-particularly economic growth as contained, for example, in the Seychelles strategy 2017 document-does not lend itself to the homogenisation of the labour market. Instead, it reinforces the duality of the market that will continue to be split primarily on the basis of some stereotypical attitudes and the price of labour, which is driven by the market forces of supply and demand. The country's split labour market is not a deliberate result of ethnocentric bias or racial hierarchy by businesses and the government, who are the two main employers of labour in the Seychelles. The duality of the labour market has emerged as an offshoot of the global designs of capitalism and specifically the exploitation and 'hierarchisation' of labour, which are inextricably tied to capitalism. It is important to highlight that despite a fundamental shortcoming of the split labour concept, in that it overlooks intra-racial, intra-ethnic exploitation, it nonetheless is a very useful instrument in helping to unmask or capture contemporary realities of the Seychelles' bifurcated labour market.

\section{Study methodology}

The primary objective of this study is to provide a descriptive account of the socioeconomic and policy constraints to the Government of Seychelles' successful implementation of its 
guidelines to the recruitment of non-Seychellois. In order to achieve the stated objective, the split labour market (SLM) theoretical framework was employed. Given the nature of the prescribed theoretical framework, this article employs a qualitative methodology using a single case study and a descriptive research approach. The descriptive approach is deemed an appropriate choice for this article, as it "is used when the purpose of research is the accurate description of a situation or an association between variables" (Kothari, 2006, p.33).

In this study, document analysis forms an integral part of the qualitative mode of inquiry, as it is used to harvest information on the Government of Seychelles' initiatives on labour market localisation and simultaneously delve into some of the systemic constraints encountered. The study reviewed key documents, including the 1996 Constitution, academic papers, newspaper articles, official government policy papers and unpublished research working papers. In addition, information for analysis is extracted from semi-structured in-depth and informal interviews with Seychellois respondents which were conducted intermittently between November 2017 and February 2018. Twenty semi-structured and ten informal interviews formed part of a more expansive research project on socioeconomic structural reforms taking place in the Seychelles in line with the International Monetary Fund and World Bank's funding conditions. The targeted population for the study was purposively sampled and interviewees drawn from state functionaries, business owner/managers and ordinary residents.

Guided sample questions that targeted interviewers were asked, including, but not limited to, the following:

i. What are some of the possible reasons why some locally and expatriate-owned businesses tend to mainly hire non-Seychellois employees?

ii. How do you feel about the growing number of expatriate workers in the Seychelles? iii. What are and likely to be some of the main impediments to the Government of Seychelles policy of 'Seychelloisation'?

iv. Are there financial and cultural advantages for Asian-owned businesses to employ almost exclusively their compatriots in the wholesale/retail business sector?

Transcribed interviews were labelled; for example, informal interview 1, semi-structured interview 1 . The order of labelling was determined by the completion of each transcription and not the order in which the interviews were conducted. The transcripts were repeatedly viewed, and the responses of respondents were treated within the parameters of the central themes, which then were triangulated with a view to establishing the consistencies, reliability and validity of the issues raised in the data collection period.

\section{The raisons d'être for the 'Seychelloisation' or localisation of the labour force}

This section delves into the policy guidelines for the recruitment of non-Seychellois by the Government of Seychelles and seeks to explain why such guidelines are deemed necessary. The exponential increase in the number of migrant workers across the archipelago has created not only a demographic shift, but also an unease amongst the Seychellois working population, who feel a sense of social exclusion and cultural dilution in their own country. This feeling of unease does not in any way negate the socioeconomic contribution that has been made by foreign 
workers to the domestic economy. In fact, one official from governing Party Leppi or Seychelles Peoples Patriotic Front (SPPF) was quoted by the Seychelles News Agency (2014) as saying, "expatriates in the Seychelles contribute essential skills and labour to the development of the country." By contrast, however, the repercussions of an unchecked dependence on expatriate labour and the shifting population ratio of expatriates to non-Seychellois can have serious repercussions on the country's limited resources including its human resources and social cohesion. The following issues discussed below necessitate the government's policy of direct intervention in the labour market.

There are private-sector employers who have long held the view that Seychellois have a relatively high reservation wage, which compels employers to bring in expatriates to fill vacancies in situations, for example, of shift work (in other words, working outside the 8 a.m. to 4 p.m. normal working hours), or where residence on remote island resorts is required (World Bank, 2011, p.vi). To get around the high reservation entry wage and other sociological issues by Seychellois, some private-sector employers have resorted to the importation of cheap labour. The vast majority of such are sourced primarily from the labour-rich exporting countries of India, Bangladesh, the Philippines and Indonesia. Put differently, some employers (including a few quasi-state institutions) in the Seychelles use Asian workers to partly undermine the position of more expensive Seychellois labour, especially in the construction and tourism sectors. However, what is paradoxical according to one senior lecturer at the University of Seychelles is that "a few foreign-owned businesses are prepared to pay non-Seychellois senior and middle managers more than what Seychellois are demanding" (Personal interview 1, November 2017). From that perspective, there is a need for effective policy directives that will achieve further localisation or 'Seychelloisation' of the labour market. Such cannot be left to the exigencies of free market forces to resolve.

Importantly, when compared to other African countries, overall unemployment in the Seychelles is low. This is due in part to a bloated public sector, with overstaffed departments. However, a recent retrenchment exercise by the government of approximately $12.5 \%$ of the public-sector workforce has increased national unemployment drastically from $1 \%$ in 2008 to $4.5 \%$ in 2009; this has since been reduced to 3.6\% (Government of Seychelles n.d.; NBS, 2015). Notwithstanding the fact that the labour market is operating at full employment level, there is growing joblessness among the youth segment of the population. This is reflected, for example, in the findings of a 2015 labour market research conducted by the National Bureau of Statistics, which revealed that:

Youth unemployment situation in Seychelles for 2014 was considered severe. The rate of youth unemployment was 3.3 times higher than the national unemployment with the age band below 25 years [remaining] the sub group with the highest unemployment rate at $13.2 \%$. (NBS, 2015, p.4)

The matter is further compounded by the recent downsizing of the public sector, and the resultant social cost of public-sector rationalization will have a disproportionate impact on youth. To put it into context, the Seychellois youth population, according to the most recent 2010 census (less than 25 years old), accounts for 38\% of the total mid-year population (United Nations Economic Commission for Africa, 2018). Youth unemployment, from a sociological 
perspective, as Farah Mohammed (2017) warns, "has ramifications beyond the purely economic sphere. Unemployment is a deeply personal problem, which can lead to internal conflict, which can express itself through external hostility." In lieu of reduced employment opportunities in the public sector and state-owned enterprises, the 'Seychelloisation' of the labour market especially amongst the youth has become a socio-political imperative.

An additional important factor that necessitates the need for the nationalisation ('Seychelloisation') of the labour force is borne out of the concern expressed by Poulan and Herm (2014), who note that a growing economy-where a significant part of the skilled labour force is foreign (i.e., non-Seychellois) - should be carefully monitored so that policy does not harm the national labour market, which can have an impact on the Seychelles' socioeconomic profile.

\section{The localization policy and programme and the new quota system}

The terms of employment in post-independence Seychelles are governed by the Employment Act of 1995, which, over the years, has been supported by a few national employment policies; the most recent was released in 2014. The Seychelles' postcolonial policy on foreign workers has evolved from one that was dependent on African slaves by European colonial settlers to a policy framework that is largely dependent upon local and international economic cycles. This determines the need for both local and foreign manpower, particularly low-skilled and unskilled foreign workers, as a stop-gap measure-specifically when the business cycle is on the growth trajectory. As of 15 May 2014, the Ministry of Labour and Human Resources Development introduced a new procedure (quota system) for recruitment of non-Seychellois workers, which works alongside a Localisation Plan, to ensure Seychellois are continuously provided an opportunity to secure employment (MLHRD, 2014).

The basis for the new quota system is threefold in terms of its overarching roles. The first role is highlighted by Lee (2016) in noting that "part of the government's strategy is to safeguard jobs for Seychellois and at the same time facilitate the procedures for recruiting and managing the employment of non-Seychellois workers." This will essentially help to solve the problem of growing youth unemployment, with a reduction in the number of unemployed Seychellois. The second role is to use the recruitment guidelines to reflect the realities of the existing labour market in a growing economy, and the third role will, theoretically, reduce the growing dependence on expatriate labour. The designs of the Seychelles labour localisation project "represents the metonym of human resources development and sociocultural empowerment within non-state-owned institutions" (Thompson \& Wissink, 2016, p.5) in the Seychelles.

\section{Unpacking the quota categories}

According to the official document from the Ministry of Labour and Human Resources Development $(2014,2016)$, the quota system has been classified into three categories, namely Categories 1, 2, and 3. The procedures for the recruitment of non-Seychellois in Category 1 does not make it obligatory for businesses to first test the domestic labour market. Companies simply must apply for an entitlement certificate, provided that a company can demonstrate or prove that it is currently adhering to all the provisions of the Employment Act of 1995 and other government regulations. Essentially, the new procedures do not require locally based companies 
within this category to first test the local market for local workers before recruiting nonSeychellois or expatriate labour.

Table 2: Classification of quota categories for non-Seychellois, Category 1.

\begin{tabular}{|l|l|l|l|l|l|l|}
\hline Category 1 & Tourism & Construction & Agriculture & Manufact. & Fisheries & $\begin{array}{l}\text { Financial } \\
\text { services }\end{array}$ \\
\hline Sub-category & & $\begin{array}{l}\text { Building } \\
\text { contractor } \\
\text { classes: 1,2,3 }\end{array}$ & $\begin{array}{l}\text { Farm size 1, } \\
2,3 \mathrm{~h}\end{array}$ & Factory size & $\begin{array}{l}\text { Semi- } \\
\text { industrial, sea } \\
\text { cucumber, } \\
\text { mariculture }\end{array}$ & $\begin{array}{l}\text { Banks, } \\
\text { auditing } \\
\text { firms, } \\
\text { insurance } \\
\text { companies }\end{array}$ \\
\hline $\begin{array}{l}\text { Quota } \\
\text { allocations } \\
\text { avg. \% age }\end{array}$ & 52 & 60 & 60 & 60 & 56.6 & 17.3 \\
\hline
\end{tabular}

Table 2 summarizes sectors and subgroups that constitute Category 1 and the average quota entitlement as per sector. For example, businesses in the construction, tourism, agriculture, manufacturing and fisheries sectors, which fall in Category 1, are entitled to have an average ratio of six expatriates to one Seychellois on the payroll. This contrasts with the financial services sector, where firms have a dependency ceiling of on average of 1.7 foreigner workers to one Seychellois worker. This figure is significantly less than the other non-financial services cluster of sectors that comprise Category 1.

The procedures for recruiting non-Seychellois in Category 2 are in direct contrast to those for Category 1. Quota entitlement for businesses that fall in this category will not be automatic: for example, with Trade and Commerce and Domestic workers for private homes for the elderly. By government policy, companies are required to test the local labour market first, through the advertisement of all vacant positions in a local newspaper(s), or through other private employment agencies, to determine whether Seychellois are available to fill the positions advertised.

Table 3: Classification of quota categories for non-Seychellois, Category 2, Trade \& commerce.

\begin{tabular}{|l|l|l|l|l|l|l|l|}
\hline Category 1, Trade \& Commerce & Import & Wholesale & Retail & $\begin{array}{l}\text { Import \& } \\
\text { wholesale }\end{array}$ & $\begin{array}{l}\text { Import \& } \\
\text { retail }\end{array}$ & $\begin{array}{l}\text { Import, } \\
\text { wholesale, } \\
\text { \& retail }\end{array}$ & $\begin{array}{l}\text { Private } \\
\text { elderly } \\
\text { homes }\end{array}$ \\
\hline $\begin{array}{l}\text { Quota allocations } \\
\text { avg. \% age }\end{array}$ & 20 & 20 & 30 & 25 & 37.5 & 47.5 & 40 \\
\hline
\end{tabular}

Table 3 shows the government's quota system is aimed at controlling semi-skilled and unskilled foreign labour in the trading sector, which is more stringent than the previously discussed category. This is reflected through the low quota ceilings in the import, wholesale retail and import/wholesale sectors. However, officials face a dichotomy in Import and Retail, Import, Wholesale and Retail and the privately-run homes for the elderly subcategories, as the average dependency ceiling or quota entitlements are significantly higher in the first three subcategories in Table 3. Similar, to data in Table 2, the Seychellois Government continues to grapple with its inability to wean the private sector off semi-skilled and unskilled foreign labour. 
In case of category three, the procedures for the recruitment of non-Seychellois in said category stipulates that applicants must first test the domestic labour market to fill their vacancies and, in the event that suitable Seychellois cannot be found to fill the advertised posts, then a certificate of entitlement to bring in non-Seychellois workers can be applied for. The MLHRD (2014, 2016) official document highlighted that:

The category of domestic workers for employment of non-Seychellois by an individual employer has been classified and defined according to the nature of the work duties. Domestic worker is taken to be any person performing work in or for a household(s) within an employment relationship. A person who performs domestic work on an occasional basis and not on an occupational basis is not a domestic worker.

The 'Seychelloisation' process of the domestic economy has been extended to regulation of foreign domestic workers in Seychelles, even though there is an abundance of anecdotal evidence that reflects the difficulty that individual employers have in recruiting domestic workers for households. In summary, all business establishments have quota entitlement in each category, which is calculated by a predetermined formula that essentially works out a company's dependency ratio ceiling or the number of foreign workers that can be employed, all things being equal in the labour market.

\section{Policy conundrum: Barriers and challenges to 'Seychelloisation'}

The localisation of employment is of the highest priority on the Government of Seychelles' development agenda. The challenge of maintaining a balance between expatriates and nationals across targeted categories, particularly in the private sector, will remain challenging for the foreseeable future. This is due to the fact there are some systemic and structural hindrances encountered in fully implementing the 'Seychelloisation' policies. The policy of localisation suffers the following epistemological realities.

\section{Policy contradictions}

Recently declared guidelines for the recruitment of non-Seychellois, with the intended quintessential objective of reducing the islands' dependence on foreign labour, is fraught with an inherent contradiction and/or paradox. Such enigma has to do with trying to balance the islands' economic imperative of rapid sustainable economic growth, whilst at the same time ensuring that the islands' citizens are not relegated to a passive subaltern group that becomes increasingly excluded from the economy. Thus, to achieve such economic imperative, the government has seemingly surrendered segments of the tourism sector to expatriate workers. For example, hotels on island resorts with 1-50, 50-100 and 100+ rooms all have entitlements of $70 \%, 75 \%$ and $80 \%$ respectively. Further policy contradiction finds expression in the fact that quotas for similar-sized hotels are slightly slower on the main islands of Mahé and Praslin.

Present and future jobs created by manufacturing companies with a labour force ranging between 200 and 1,000 (and above) will primarily be filled by comparatively cheap imported labour, due in part to the disproportionate allocation of quotas that have an appetite for nonSeychellois workers in the manufacturing sector. This is a fundamental policy contradiction, 
which places the Government of Seychelles on the horns of a practical and policy dilemma as high quota entitlement is in opposition to suggested human resource practices that would facilitate employment of nationals. This is not dissimilar to what prevails in the agriculture and fisheries sectors that have inexplicable high ratios of expatriate to local workers. By maintaining the ratios above, of foreign labour to domestic workers, and notwithstanding the narrative to reduce the dependence on foreign labour, the government's 2014/2016 policy framework undermines and represents a reticence in dealing with the issue of growing presence of foreign workers on the islands. There is a dialectic discourse amongst academics and policy analysts on the main island of Mahé that the hands of the government are tied, as without excessive presence of foreign workers in some sectors the islands would not achieve the development of a highly sophisticated and globalized private sector. These factors exert paradoxical pressures on policymakers and create real challenges to policymaking.

\section{Perception and tacit social exclusion}

The Seychellois Government recognises the right of every citizen to work and to a just and favourable condition of work as expressed in Article 35 of the 1996 constitution. As such, guidelines for the recruitment of non-Seychellois workers in the private and public sectors are fortified by regulatory safeguards. Running parallel to such regulatory safeguards is a lingering allo-cultural or allocentric view of Seychellois levels of commitment and attitude towards their work. This bears out in the example, mentioned earlier, of the third interviewee, who noted, "Indians are more committed, reliable and have a higher level of attendance than Seychellois." Another respondent is of the view that Indian employees in general are more pliable and are prepared to endure harsh working conditions, without complaining openly to management (Personal Interview 6, February 2018). These generalised beliefs, characteristics, attributes and behaviour about some members (Hilton \& von Hipple, 1996) of the Seychelles' multiracial society have propelled an increasing number of local and foreign companies to favour expatriates for managerial and technical positions across various sectors in the country. The unsavoury stereotypical imagery conjured up by many business personnel has been reinforced by many government departments and semiautonomous government entities. The University of Seychelles is one such institution that has a penchant for expatriate lecturers and senior management staff.

Social 'hierarchisation' as encapsulated through stereotypical negative perceptions and prejudices against low- and semi-skilled Seychellois workers by the growing expatriate capitalist class underscores the sociocultural binaries that generally view Seychellois at the lower rungs of the labour market ladder as negative versions of social capital. This is in addition to anecdotal evidence and direct observation by the authors of pervasive employment of Asians specifically in retail shops in the communities of Glacis, Victoria, Anse Royale and Pointe Au Sel. There is the suggestion by many Asian or Russian business owners/managers that religious, cultural or ethnolinguistic factors are the fundamental reasons for employing their own compatriots as opposed to Seychellois. The ramification of such exclusionist employment continues to find expression in the increasing exodus of specially trained and highly skilled Seychellois. 


\section{An emerging 'mudir syndrome'}

The concept of 'mudir (boss) syndrome' was coined and popularised by Daryl Champion in an attempt to explain the power relations and attitudes of Saudi Arabians toward jobs in the lower spectrum of the Saudi Arabian labour market (Thompson \& Wissink, 2016, p.8). Henry and Springborg's (2001, p.181) use of Daryl Champion's (1999) concept, describes the 'mudir syndrome' concept as an "honour in employment which dictates that nothing less than a position of authority, status and respect is acceptable." This mentality emanates out of cultural values, and what has been regarded by Budhwar and Mellahi (2006, p.132) "as social values that inscribe big egos and immense sense of pride of the Arabian people." When applied to the Seychelles, a former postcolonial slave society, this emerging sociological phenomenon- especially among the youth - springs from the islands' newly found middle-income country status. This is further intertwined with an attachment to the government's generous social welfare system that serves as a disincentive to work in certain perceived undesirable jobs. Essentially, there is a social hierarchy that has been informed by the status ascribed to a particular occupation. The partial or even full applicability of the concept to the business-labour relations in the Seychelles finds expression in a number of ways. For example, Temesgen, Harnack and Oduor (2016, p.11) bemoan the "persistent selectivity of young Seychellois in respect of the jobs they accept (poor work ethics is the second problem affecting doing business according to the GCR 2014-15 survey)." The IMF (2013) notes that the modern Seychellois youth would prefer to rely on family networks for support than to take undesirable jobs.

The effect of the emerging 'mudir syndrome' phenomenon in the Seychelles is similar, to a large degree, to what occurs in the Arabian Gulf States of Qatar, Saudi Arabia and the United Arab Emirates. As Tardif (2011, p.84) contextualizes, the existence of the mudir syndrome compels business and government to "employ temporary expatriate workers to carry out tasks that local Emiratis will not and do not wish to perform." Similarly, in the Seychelles, employment of expatriate nurses (Table 4) in privately run homes for the elderly, and workers in the construction, tourism, agriculture and fisheries industries, are less restrictive than in the financial services sector. In an informal interview, an academic on the island bemoaned the lack of interest in certain job types by Seychellois, especially postsecondary school graduates.

Despite the varying degree of applicability of the concept, the syndrome has contributed to a relatively limited number of Seychellois accepting certain types of jobs in the tourism industry and tuna processing establishments. The interweaving of the 'mudir syndrome' and split labour market thesis explain (in part) the reason(s) as to why some Seychellois do not avail themselves to perform so-called peripheral and menial jobs that are beneath them and would prefer to extract rent from the state in the form of generous welfare benefits that are made available to them. The process of the 'Seychelloisation' of the labour force and the full implementation of government policy directive is likely to be undermined by the sociological binaries discussed above.

\section{Rent extraction}

For almost four decades, the Seychellois population and government have eked out a living by becoming interwoven into an ecosystem that Collier (2005, p.48) describes as a "system of dual clientelism." In this system, for example, the Seychellois political class acts as benefactors to its rent-seeking citizenry, whilst concurrently remaining entrenched in a form of external 
dependency in which the local political class and the state act as clients to sympathetic governments and multilateral financial institutions. Using a socialist-type state-led development model, Parti Lepep or the Seychelles Peoples Patriotic Front (SPPF) through a highly politicised public bureaucracy "has provided the Seychellois population with basic needs and services such as decent housing, free education, free primary healthcare, subsidized potable water and domestic energy, which have been central to government's poverty-reduction planning" (Campling \& Rosalie, 2006, p.120). In describing the nature of 'rentierism' in the Arabian Gulf States (AGS), Davidson (2008, pp.177-178) raised a concern that "rentier structures tie the hands of the government to the burdensome distributive practices and breed a certain unproductive mentality among the indigenous population." Similarly, in the Seychelles, its system of dual clientelism has infused a sense of parasitical rent-extracting attitude by citizens from a state that is firmly anchored in a model of rent-distribution or political patronage. As explained by Mazepus, Veenendaal, McCarthy-Jones and Vásquez (2016, p.361), "Parti Lepep continues to emphasize the redistributive nature of its policies, and its goal of realizing greater socioeconomic equality and the emancipation of the working classes." Even though the rentier policies as practiced in the Seychelles support domestic political legitimacy, they are in direct opposition to labour market localisation policies and will hamper the success of the new 'Seychelloisation' project as it relates to a prescribed entitlement quota under the refined categories.

\section{Conclusion and recommendations}

This article delves not only into the demographic structure changes, but also the changing labour market policy landscape that has been taking place in the Seychelles. Such demographic changes are due to the islands' growing dependence on foreign labour based on a multiplicity of economic and non-economic factors. Thus, as an offshoot of such factors, the present government has had to design and implement regulatory and labour policies to address a growing trend of substituting Seychellois labour for cheap imported labour from Asia and continental Africa. This is occurring in economic sectors where the Seychellois reserve wage is too high, where the supply of local labour has been withdrawn due to the 'mudir syndrome', and where there is a genuine shortage of labour with specific skill sets.

Further discussion in the body of the article highlights the fact that issues of the greater localisation of the Seychelles active labour force are complicated and cannot be resolved exclusively using employment quotas in the identified three major categories. It was argued earlier that there is an element of embedded economic discrimination that manifests itself in income disparities between and across various groups supplying their labour to the domestic market. This is just one of many constraints that will impede the government from achieving its intended success from the implementation quota-based policy.

Implicit in the findings and discussions of this research is the relevance and applicability to other microstates and/or SIDS that are faced with a similar conundrum of depending on imported labour. The relevance and applicability of this research is that it raises important fundamental issues for policymakers. Such challenges include (1) the intractable universal sharp divergence between the national development strategies and internal hiring decisions of domestic and locally based foreign companies; (2) making labour market hiring more rigid through state-sponsored regulations requires that state functionaries are equipped with the 
implementation capacity; and (3) the implementation of the quota system for the employment of non-Seychellois workers in the private sector demonstrates the importance of government intervention in the labour market to act as referee in the smoothing out of the barriers to employment of local labour.

\section{Recommendations}

- In consultation with all stakeholders in the economy, the Government of Seychelles should initiate extensive labour market reform to address not only the mismatch of skill sets in the economy, but also to engender an attitudinal shift by Seychellois towards certain occupational groups.

- The Ministry of Labour and Human Resources Development needs to go beyond crafting policy in isolation and simultaneously embark on a campaign to reverse the built-in bias against Seychellois workers where it exists in non-indigenous segments of the private sector.

- The Minister for Labour and Human Resource Development needs to revisit high quotas provided for nurses in private nursing homes for the elderly, money exchanges, in factories of all sizes and across the fishing industry.

- Greater vigilance is needed to reduce the number of foreign workers who tend to feature prominently and visibly in the wholesale and retail sectors.

- The Government of Seychelles should consider accelerating a comprehensive set of parallel policies that are aimed at integrating the youth segment of the population into productive activities.

\section{References}

Bernstein, D. (1998). Strategies of equalization, a neglected aspect of the split labour market theory: Jews and Arabs in the split labour market of mandatory Palestine. Ethnic and Racial Studies, 21(3), 449-475. https://doi.org/10.1080/014198798329900

Bonacich, E. (1972). A theory of ethnic antagonism: The split labour market. American Sociological Review, 37(5), 547-559. https://doi.org/10.2307/2093450

Bonacich, E. (1979). The past, present and future of split labor market theory. Research in Race and Ethnic Relations, 1, 17-64.

Bonacich, E. (1981). 'Capitalism and race relations in South Africa: a split labor market analysis'. Political Power and Social Theory, 2, 279-336.

Budhwar, P.S., \& Mellahi, K. (2006). Managing human resources in the Middle East. New York: Routledge.

Buzdugan, R., \& Halli, S. (2009). Labor Market Experiences of Canadian Immigrants with Focus on Foreign Education and Experience. The International Migration Review, 43(2), 366-386. https://doi.org/10.1111/j.1747-7379.2009.00768.x

Campling, L., \& Rosalie, M. (2006). Sustaining social development in a small island developing state? The case of Seychelles. Sustainable Development, 14, 115-125. https://doi.org/10.1002/sd.298

Campling, L., Confiance, H., \& Purvis, M. H. (2011). Social policies in Seychelles. London: Commonwealth Secretariat.

Champion, D. (1999). "The Kingdom of Saudi Arabia: elements of instability within stability". Middle East Review of International Affairs, 3(4), 49-73. 
Charlier, F. (2016). Cluster country programme evaluation on small states: Seychelles country case study (FY07-15), enhancing competitiveness and private sector development. Washington, DC: World Bank Group. https://doi.org/10.1596/25195

Collier, M.W. (2005). Political corruption in the Caribbean basin: constructing a theory to combat corruption. London: Routledge. https://doi.org/10.4324/9780203942703

Corzine, J., Corzine-Huff, L., \& Creech, J.C. (1988). The tenant labor market and lynching in the south: a test of split labor market theory. Sociological Inquiry, 58, 261-278. https://doi.org/10.1111/j.1475-682X.1988.tb01061x

Davidson, C. (2008). Dubai: The vulnerability of success. New York: Columbia University Press.

Government of Seychelles (n.d). Decent work country programme 2011-2015 Seychelles. Retrieved from http://www.employment.gov.sc

Henry, C.M., \& Springborg, R. (2001). Globalization and the politics of development in the Middle East. Cambridge: Cambridge University Press.

Hilton, J.L., \& von Hipple, W. (1996). Stereotypes. Annual. Review. Psychology, 47, 237-271. http://doi.org/10.1146/annurev.psych.47.1.237

Houbert, J. (2002). [Review of book Seychelles since 1760: a history of a slave and post-slavery society by D Scarr]. Journal of the International African Institute, 72(2), 329-334. https://doi.org/10.2307/3556999

International Monetary Fund. (2013). Seychelles: 2013 Article IV consultation, Seventh review under the extended arrangement and request for modification of performance criterion. International Monetary Fund. https://doi.org/10.5089/9781484384404.002

International Organization for Migration (2014). Migration in Seychelles: A country profile 2013. International Organization for Migration. Retrieved from. http://www.iom.int

Kothari, C.R. (2006). Research methodology techniques. Delphi: Dharmesh Printers.

Lee, S. (2016, January 19). Employment Seychellois versus expatriates. Today in Seychelles Daily. Retrieved from http://m.facebook.com/todayinsey/posts/92873473807130

Mazepus, H., Veenendaal, W., McCarthy-Jones, A., \& Vásquez, J. (2016). A comparative study of legitimation strategies in hybrid regimes. Policy Studies, 37(4), 350-369, http://doi.org/10.1080/01442872.2016.1157855

Ministry of Labour and Human Resources Development. (2014). Guideline for recruitment of nonSeychellois workers. Victoria: Government of Seychelles.

Ministry of Labour and Human Resources Development. (2016). Guideline for recruitment of nonSeychellois workers. Victoria: Government of Seychelles.

Mohammed, F. (2017, June 12). Could youth unemployment in the Middle East be dangerous? JSTOR Daily. Retrieved from https://daily.jstor.org/could-youth-unemployment-inmiddle-east-be-dangerous/

NBS (2015). Quarterly unemployment statistics 2014-Q4. National Bureau of Statistics. Retrieved from http://www.nbs.gov.sc/downloadarchive/resources/uploads/2015/03/Unemployment-Statistics-2014-Q4.pdf

Poulan, M., \& Herm, A. (2014). Migration in Seychelles: a country profile 2013. Geneva: International Organization for Migration. 
Seychelles News Agency (2014, July 26). Seychelles migration profile: immigration and employment at a crossroads. Seychelles News Agency. Retrieved from http://www.seychellesnewsagency.com/articles/1039/Seychelles + migration + profile $+\mathrm{i}$ mmigration + and + employment $+a t+a+$ crossroads

Tardif, E. (2011). Culture shocks in a globalized world: how 'accommodating' do states need to be regarding the use of religious symbols in the public sphere? International Journal of Public Law and Policy, 1, 88-99. https://doi.org/10.1504/ijplap.2011.041891

Temesgen, T., Harnack, J., \& Oduor, K. (2016). Seychelles 2016: African economic outlook. Retrieved from http://www.africaneconomicoutlook.org/seychelles

Thompson, P., \& Wissink, H. (2016). Political economy and citizen empowerment: strategies and challenges of Emiratisation in the United Arab Emirates. Acta Commercii, 16(1), 1-9. https://doi.org/10.4102/ac.v16i1.391

United Nations Economic Commission for Africa. (2018). Seychelles: country profile 2017. https://doi.org/10.1163/2213-2996 flg com 166144

Vannier, R., \& Uranie, S. (2014, August 3). Seychelles is encouraging the construction of adequate housing for foreign workers. Seychelles News Agency. Retrieved from http://www.seychellesnewsagency.com/articles/1090/Seychelles + is +encouraging + the + construction + of + adequate + housing + for + foreign + workers

World Bank (2011). Seychelles selected issues: social protection, labour market and public. Enterprise Reforms-Public Expenditure Review 2. Report No. 57113-SC. World Bank.

World Bank. (2018). FY18-FY23 Country partnership framework for the republic of Seychelles. World Bank. https://doi.org/10.1596/30225 